\title{
Evaluation of Visual Arts Lesson Gains According to the Learning Steps of Cognitive, Affective Psychomotor Areas
}

\author{
Eylem Tataroğlu ${ }^{1}$ \\ Department of Visual Arts and Desig, Faculty of Fine Arts, Design and Architecture, \\ Baskent University, Turkey \\ E-mail: etataroglu@baskent.edu.tr
}

\begin{abstract}
Primary education (1-8 Grades) Visual Arts Instruction Schedule is a program built up and constituted by a commission composed of academicians and specialist teachers in their fields within the body of Ministry of National Education in year 2006 on the basis of "constructivist approach" philosophy of education. Instruction Schedule composed by three learning fields, whichever philosophy of education they serve for, they have to be incentive and feeding the gains of three fields evenly for cognitive, affective and psychomotor learning looked for in ethically and educational sciences and be appropriate for the particularity of the course. On the other hand, instruction schedule also should consider the requirements of the era. This studyhas been structured upon the research in which the teaching program is separated into cognitive, affective and psychomotor field skills and which has been previously published in the journal of National Education, issue number 190. What is targeted in this paper is, to classify and evaluate 1-8 grade gains of just structured instruction schedule within the boundaries of learning fields in accordance to cognitive, affective and psychomotor learning conditions.
\end{abstract}

Key words: visual arts, cognitive, affective, psychomotor

As it has been mentioned in National Education Basic Law, it is the basic obligation of schools to bring up citizens who are devoted to Atatürk's principles and reforms and nationalism of Atatürk, was in the Constitution, who adopt, protect and develop national, moral, humanist, sentimental and cultural values of Turkish nation, who love and always improve their families, country and nation, who know and perform their duties and responsibilities towards human rights and Republic of Turkey, who is a secular and social constitutional state relying on the basic principles of Constitution.

James and Dewey base the philosophy of education on science and scientific method. This philosoph of education whose origin is "pragmatism", lately called "re-constructionism", supports the basic foundations of "constructionism" today. According to this comprehension, "it's school's basic responsibility to change the society. Teacher has the basic power here. Teacher should set all equipments which will reach these aims, and strategies, methods and techniques of teaching and learning to work" (Sönmez, 1994, p. 113).

It's useful to define the education functionally at this point: "Education is the way for socialization of the individual as much as his individualisation. The individualisation of the individual means development of self confidence and self-regulatory mechanisms." (Ada et al., 2008, p. 135). The socialization of the individual can be described as being cultured via education and using the gains of it for the society.

General function of schools and other educational institutions is to make students fit in by introducing the culture and to teach them the ways of improving the culture to make them keep up with the conditions of the changing world and times (Varış, 1976, 16). One of the most important factors which nourishes and forms the culture is art. The first point where art meets the student in formal education systematically is visual arts lesson. This lesson focuses on the issued of the children's, between 
$7-15$, self expression, fitting in and being aware towards the society and the environment. The name of the lesson has changed depending on the enlargement of the content. Art education has devided in three learning areas into the programme and gains from the lesson has been specified incrementally in each level in accordance with knowlegde, ability and habits which are expected from the student by taking into the minimum needs of the individual consideration to be an art-educated adult (MEB, 2007, 13).

Education programmes aims to upskill. "The individual has to be born and grow up in a society, get in touch with people, have a proffesion and work in a group, and will face with suchlike social obligations; that's why he/she must be upskilled in school to be able to do anc achieve them" (Demirel, 2007, p. 43). In this respect, visual arts lesson is a culture lesson with the aim of providing abilities and competences carefully because when stages of personal growth is taken into account, it covers the years when an individual reaches puberty after first, middle and childhood stages.

"Evolution occurs as a result of growth, maturation and learning." (Bacanl1, 2002, p. 41). Because of this fact, aarthistic sensitivity which will complete the individual, is programmed in order for her/him to grow up healthily. As is known, every characteristic is added on the previous ones (Bacanl, 2002, p. 43). Therefore it is expected for gains from programme which has been prepared according to improving each of these three stages to be staggered. Growing functions of each age are different and according to the targets education programme is expected to be directive and supporting for studens to develop the abilities and attitudes for the duties of their ages. Ofcourse this motivation function is not the only responsibility of this programme; The teacher who applies the programme, parents and environment also should be "sensitive" and "aware" of the child's growing duties and needs. But it must be known that a well-designed programme is a perfect lodestar and dynamic power for both student's and teacher's education. The focal point of this research is formed exactly by this point of view: "Could visual arts programme define the student in compliance with his/her growing duties? Does the schedule have gains which allude to cognitive, affective and psychomotor abilities, arranged properly for every level?" In order to reply these questions, it will be useful to give short preliminary information and abstract about developing a schedule.

It is known that four stages are used to prepare curriculum. These stages can be summarized briefly like that:

1. Why do we educate? The aims of education are determined.

2. What shall we teach? Content is specified. Subjects and units, forming the content, are determined.

3. How shall we teach? Teaching processes and educational status are determined.

4. How many of the aims are achieved? Assessment and evaluation are made.

Because of the fact that the evaluated one for education and training is "human", human must be known well. From Ertürk's point of view "each person is born in a specific culture as an organism with some features and grows up by getting culture from that society; namely human is a bio-cultural and social creature" (Ertürk, 1993, p. 3). This idea is supported by the view of human's being recreated by acculturation from society and the importance of education is emphasized in this way. Acculturation can be defined as "gaining the features of the culture where the individual lives in (Ertürk, 1993, p. 7). 1.1. Why do we educate? Targets in education can be considered in different aspects. Distant target, general targets and special targets are the answer of the question "Why do we educate?" Distant target represents the political philosophy. "Which philosophy is used as a base affects how people are seen and the education system is arranged according to it" (Sönmez, 1994, p. 57). If pragmatical, progressive and re-constructive education movements are used as a base, each person is educated according to his/her skills and interests (Sönmez, 1994, 60). In this sense, it is needed to bring up people who can 
live in a balance with every culture, not people who can just settle himself in a specific environment. The function of the philosophy consists of in which direction training services are set to work. Distant target is useful for us to specify our direction while determining the targets (Ertürk, 1993, p. 14). General targets can be considered in two categories as education's and schools. Education's general target can be considered as an interpretation or even inditement of the distant target (Ertürk, 1993, p. 14-15). Special targets are prepared for discipline or studying areas which are suitable features for a student to gain. In a discipline or studying area, suitable knowledge acquisition is the features such as skill, ability, interest, attitude and habits (Bilen, 1993, p. 2).

1.1.1. Progressive Classification: It is seen that the progressive classification, made by Bloom and his collogues, is adopted and become widespread among related environments. According to the principles which have formed, improved and spread in the last twenty years, targets were considered in three main areas as cognitive, affective and psychomotor and were improved with detail of progressive classification in these areas (Ertürk, 1993, p. 63).

1.1.1.1. Cognitive Area: In cognitive area, there are six stages: knowledge, comprehending, performing, analysis, synthesis and evaluation. It is the area consisting the individual's intellectuality. Cognitive activities are in the foreground. It is the area consisting learnt behaviors.

Knowledge: It is the area where student does not add anything from himself. It is the base to make him gain behaviors in the other stages. It consists of two stages, identification and remembrance.

Comprehending: The student is on the level of comprehending if he can illustrate, draw a graph of something non graphic, and presume about future by using the present information, if he has skills like communicating. This means he takes over what he learns. A student on this level can compare what he learns to the previous ones and make a new interpretation.

Performing: It is the process of solving problems. If student can use what he learns in a new area when he faces with a problem, he is on the level of performing.

Analysis: It is the stage of dividing information into parts and finding the connection between them. It determines the main principles and rules on which relations base.

Synthesis: Combination. This is a new (original) product. It is to present a production representing the feelings and ideas of the person (it is also related to original one.). It also contains psychomotor behaviors (writing a poem, projecting etc.).

Evaluation: It has two types: with internal criteria and with external criteria. Evaluation is the process of determination.

Evaluation with external criteria: It is to evaluate by comparing the products with each other.

Evaluation with internal criteria: It is to evaluate by regarding the criteria that are supposed to be in this product.

1.1.1.2. Affective Area: It is the area about the feeling of the person. It contains the main features which make people human. Academic self-concept, love, hatred etc.are in this area. Affective behaviors can be given to the student just by being a model. Make the student gain the affective behaviors which is very difficult to give, is the most important duty of schools. It consists of receiving, reacting, appreciation, organizing and describing stages.

Receiving: This is the simplest stage. It's connected with the stage of knowledge. The person realizes most premonitories, becomes given on to it and ready to receive it.

Reacting: The person reacts to the premonitory. This reaction can be in the ways written below:

Forcing: It is an external reaction. It occurs by force; this reaction occurs whether student wants or not. For example, when teacher enters the classroom, the students stop speaking.

Eagerness: The student joins the activities and lessons ambitiously. 
Satisfaction in reaction: The student enjoys the reaction that he receives.

Appreciation: This is one of the most important stages. Until the secondary education, affective skills are gained. Values of the society are realized. This is the first step of the development of the values and beliefs. That's why; rooter values should not be gained.

Organizing: This stage is in the steps of analysis and synthesis. Values are examined and conceptualized. The person continues his life in a consequent way with values.

Describing (Personality): Personality shapes. Due to the behaviors, the person is described. The individual starts to live according to the values and his point of view is formed.

1.1.1.3. Psychomotor Area: They are the features which require the coordination of the brain and muscles. This is the subject area of the questions, what to do, what to use and how much to use. In this stage, it is focused how to use muscles more effectively in a short time. Psychomotor area features are able to be measured easily and simultaneously. It is essential to check the affective area behavior markers for this. It consists of stimulation, making with a guide, making it a skill, customizing and creating stages.

Stimulation: This means making the body ready. It consists of perception and bodily setup stages.

Making with a Guide: This stage contains making by imitating under the control of a teacher. The teacher must give each student a feedback. It is essential to give feedback immediately in order to prevent mislearnings.

Making It a Skill: This is to do something in the way it should be. If the student can do something well, it means that he is on this level. Here "well" means to do something at will, effectually (perfectly).

Customizing: This is to perform the learnt information and skills without difficulties after one or two tries.

Creating: This is the highest qualification. This is the level where special gifted people are.

1.2. What will we teach? We can classify the contribution of a specific subject to the individual's right into two groups. Attainments which will be gained from a study on a specific subject, can constitute to the works' base of the individuals who will specialize on this subject. However, it is useful to make people who will not specialize on this subject, gain, in other words education must involve gains and patterns which has wider target areas. In the aspect of content, it is possible to see that Visual Arts Instruction Schedule in Primary Education has been developed in three basic learning areas:

1.2.1. Figuration in Visual Arts: It is based on teaching and evaluating the organization according to the principles of art factors' artistic organization in the learning area which constitutes the base of this lesson with other learning areas (Peşkersoy ve Yıldırım, 2008, 12). In this respect, it can be said that psychomotor and cognitive processes have been considered more.

1.2.2. Culture of Visual Arts: This learning area where it is aimed to teach some disciplines such as esthetics, art history and criticism of art, aims to develop affective skills more.

1.2.3. Museum Consciousness: It can be said that Affective skills are cared more because it aims to develop a "consciousness" as it can be understood by its name. However, it is also a learning area which contains cognitive and psychomotor learnings because it develops an attitude towards the solution of the problem arising from knowing and understanding culture inheritance. 
The attainments of this three learning areas will be separated as attainments aiming cognitive, affective and psychomotor learning with tables. It can be useful to summarize these learnings and their stages in the next chapter.

1.3. How Will We Teach? It is in the problem area of this stage to bring the student the aimed qualification by knowing the learning style of the student and using right techniques. For this, the most important point which must be accepted is to know that the person is "unique" and has original skills and considering this, similar unique techniques will be used. "Style is the general feature composed out of the person's constant tendencies and choices. Style has a feature which distinguishes the person from others, which is about working both intellectually and personally, belonging to him (Güven, 2004, 21).

1.4. How many of the aims are achieved? The important point here is to measure and evaluate if the student gained the habits which were supposed to be gained by him. Moreover, the obtained data and success of the student provide a feedback to improve the curriculum.

\section{Procedure}

This research is a descriptive study. Descriptive researches are generally made to enlighten a case, make evaluation according to standards and develop possible relations between incidents. In these kinds of researches, the aim is to describe and explain the case in dept (Çepni, 2007, 34). In this research, firstly, literature has been reviewed. Secondly, the attainments from visual arts lesson in primary education have been classified according to grades and cognitive, affective and psychomotor features. Finally, statistical data from these classes are obtained and interpreted.

\section{Findings and Interpretation}

\section{Classification of the Attainments from Visual Arts Lesson on 1st Grade}

Table 1. Distribution of the Attainments from Visual Arts Lesson on 1st Grade According to Cognitive, Affective and Psychomotor Areas

\begin{tabular}{ccc}
\hline Learning Area: Creating Awareness In Visual Arts & \\
Cognitive Area & Affective Area & Psychomotor Area \\
4. attainment & 6. attainment & 1. attainment \\
5. attainment & 7. attainment & 2. attainment \\
6. attainment & & 3. attainment \\
& & 4. attainment \\
& & 6. attainment \\
& & 7. attainment \\
Learning Area: Visual Arts Culture & & Psychomotor Area \\
Cognitive Area & Affective Area & 3. attainment \\
7. attainment & 1. attainment & 4. attainment \\
9. attainment & 2. attainment & 10. attainment \\
& 3. attainment & \\
& 5. attainment & \\
& 6. attainment & \\
8. attainment & & \\
Learning Area: Museum Consciousness & Affective Area & Psychomotor Area \\
Cognitive Area & 2. attainment &
\end{tabular}


\begin{tabular}{l|l|l} 
& 3. attainment & 4. attainment
\end{tabular}

There are totally 21 attainments from the visual arts lesson on 1st grade of primary education. 6 of these attainments are in cognitive area, 10 of them are in affective area and 11 of them are in psychomotor area. When it is counted by percentages, it is seen that $28 \%$ of the attainments are in cognitive area, $47 \%$ of them are in affective area and $52 \%$ of them are in psychomotor area. As it is seen in the table, an attainment can have more than one area skill.

\section{Classification of the Attainments from Visual Arts Lesson on 2nd Grade}

Table 2. Distribution of the Attainments from Visual Arts Lesson on 2nd Grade According to Cognitive, Affective and Psychomotor Areas

\begin{tabular}{ccc}
\hline Learning Area: Creating Awareness In Visual Arts & Affective Area \\
Cognitive Area & 7. attainment & Psychomotor Area \\
2. attainment & 8. attainment & 1. attainment \\
3. attainment & & 2. attainment \\
5. attainment & & 4. attainment \\
6. attainment & & 6. attainment \\
7. attainment & & 7. attainment \\
& & 8. attainment \\
Learning Area: Visual Arts Culture & Affective Area & \\
Cognitive Area & 1. attainment & Psychomotor Area \\
1. attainment & 2. attainment & 2. attainment \\
4. attainment & 3. attainment & 3. attainment \\
5. attainment & 4. attainment & 7. attainment \\
7. attainment & 6. attainment & \\
& 7. attainment & \\
Learning Area: Museum Consciousness & Affective Area & \\
Cognitive Area & 1. attainment & Psychomotor Area \\
2. attainment & 2. attainment & 1. attainment \\
& 4. attainment & 3. attainment \\
\hline
\end{tabular}

There are totally 19 attainments from the visual arts lesson on the 2nd grade of primary education. 10 of these attainments are in cognitive area, 11 of them are in affective area and 11 of them are in psychomotor area. When it is counted by percentages, it is seen that $52 \%$ of the attainments are in cognitive area, $57 \%$ of them are in affective area and $57 \%$ of them are in psychomotor area. The attainments which were shown in bold can have more than one area skill.

\section{Classification of the Attainments from Visual Arts Lesson on 3rd Grade}

Table 3. Distribution of The Attainments From Visual Arts Lesson on 3rd Grade According to Cognitive, Affective and Psychomotor Areas

(C) 2012, European Journal of Educational Research, 1(2), 65-83 


\begin{tabular}{ccc}
\hline Learning Area: Creating Awareness In Visual Arts & \\
Cognitive Area & Affective Area & Psychomotor Area \\
2. attainment & 14. attainment & 1.attainment \\
3. attainment & & 3. attainment \\
4. attainment & & 5. attainment \\
7. attainment & & 6. attainment \\
8. attainment & & 8. attainment \\
9. attainment & & 9. attainment \\
10. attainment & & 10. attainment \\
11. attainment & & 12. attainment \\
13. attainment & & 13. attainment \\
Learning Area: Visual Arts Culture & & 14. attainment \\
Cognitive Area & Affective Area & \\
3. attainment & 1. attainment & Psychomotor Area \\
4. attainment & 2. attainment & 1. attainment \\
5. attainment & 5. attainment & 6. attainment \\
Cearning Area: Museum Consciousness & & \\
Cognitive Area & Affective Area & \\
1. attainment & 1. attainment & Psychomotor Area \\
2. attainment & 3. attainment & 3. attainment \\
3. attainment & & 4. attainment \\
\hline
\end{tabular}

There are totally 24 attainments from the visual arts lesson on the 3rd grade of primary education. 15 of these attainments are in cognitive area, 6 of them are in affective area and 14 of them are in psychomotor area. When it is counted by percentages, it is seen that $62 \%$ of the attainments are in cognitive area, $25 \%$ of them are in affective area and $58 \%$ of them are in psychomotor area. The attainments which were shown in bold can have more than one area skill.

\section{Classification of the Attainments from Visual Arts Lesson on 4th Grade}

Table 4. Distribution of The Attainments from Visual Arts Lesson on 4th Grade According to Cognitive, Affective and Psychomotor Areas

\begin{tabular}{lcc}
\hline Learning Area: Creating Awareness In Visual Arts & \\
Cognitive Area & Affective Area & Psychomotor Area \\
2. attainment & 2. attainment & 1. attainment \\
3. attainment & 4. attainment & 10. attainment \\
4. attainment & 9. attainment & 14. attainment \\
5. attainment & 14. attainment & \\
6. attainment & & \\
7. attainment & & \\
8. attainment & & \\
11. attainment & & \\
12. attainment & & \\
Learning Area: Visual Arts Culture &
\end{tabular}


Cognitive area

1. attainment

2. attainment

4. attainment

7. attainment

Learning Area: Museum Consciousness

Cognitive Area

1. attainment

2. attainment

4. attainment

5. attainment
Affective area

3. attainment

5. attainment

Affective Area

5. attainment
Psychomotor area

4. attainment

6. attainment

Psychomotor Area

3. attainment

5. attainment

There are totally 26 attainments from the visual arts lesson on the 4th grade of primary education. 17 of these attainments are in cognitive area, 7 of them are in affective area and 7 of them are in psychomotor area. When it is counted by percentages, it is seen that $65 \%$ of the attainments are in cognitive area, $26 \%$ of them are in affective area and $26 \%$ of them are in psychomotor area. The attainments which were shown in bold can have more than one area skill.

\section{Classification of the Attainments from Visual Arts Lesson on 5th Grade}

Table 5. Distribution of the Attainments From Visual Arts Lesson on 5th Grade According to Cognitive, Affective and Psychomotor Areas

\begin{tabular}{ccc}
\hline Learning Area: Creating Awareness In Visual Arts & Psychomotor Area \\
Cognitive Area & Affective Area & 1. attainment \\
2. attainment & 3. attainment & 2. attainment \\
4. attainment & 6. attainment & 3. attainment \\
5. attainment & 9. attainment & 5. attainment \\
9. attainment & 10. attainment & 7. attainment \\
& & 8. attainment \\
& & 9. attainment \\
& & 10. attainment \\
Learning Area: Visual Arts Culture & & Psychomotor Area \\
Cognitive Area & Affective Area & 6. attainment \\
1. attainment & 3. attainment & \\
2. attainment & 5. attainment & \\
3. attainment & 7. attainment & \\
4. attainment & & \\
5. attainment & & \\
7. attainment & & Psychomotor Area \\
COGNITIVE AREA & & 4. attainment \\
2. attainment & 1. attainment & 5. attainment \\
3. attainment & 2. attainment & \\
& 5. attainment &
\end{tabular}

(C) 2012, European Journal of Educational Research, 1(2), 65-83 
There are totally 22 attainments from the visual arts lesson on the 5th grade of primary education. 11 of these attainments are in cognitive area, 9 of them are in affective area and 11 of them are in psychomotor area. When it is counted by percentages, it is seen that $50 \%$ of the attainments are in cognitive area, $40 \%$ of them are in affective area and $50 \%$ of them are in psychomotor area. The attainments which were shown in bold can have more than one area skill.

\section{Classification of the Attainments from Visual Arts Lesson on 6th Grade}

Table 6. Distribution of the Attainments from Visual Arts Lesson on 6th Grade According to Cognitive, Affective and Psychomotor

\begin{tabular}{ccc}
\hline Learning Area: Creating Awareness In Visual Arts & \\
Cognitive Area & Affective Area & Psychomotor Area \\
2. attainment & 5. attainment & 1. attainment \\
3. attainment & 8. attainment & 3. attainment \\
4. attainment & 9. attainment & 6. attainment \\
6. attainment & & 7. attainment \\
7. attainment & & 8. attainment \\
& & 9. attainment \\
Learning Area: Visual Arts Culture & Affective Area & Psychomotor Area \\
Cognitive Area & 3. attainment & 4. attainment \\
1. attainment & 5. attainment & 6. attainment \\
2. attainment & 7. attainment & \\
3. attainment & 8. attainment & \\
5. attainment & & \\
7. attainment & & \\
8. attainment & & Psychomotor Area \\
Learning Area: Museum Consciousness & Affective Area & 4. attainment \\
Cognitive Area & 2. attainment & 5. attainment \\
1. attainment & 5. attainment & 6. attainment \\
3. attainment & 6. attainment &
\end{tabular}

There are totally 23 attainments from the visual arts lesson on the 6th grade of primary education. 14 of these attainments are in cognitive area, 10 of them are in affective area and 11 of them are in psychomotor area. When it is counted by percentages, it is seen that $60 \%$ of the attainments are in cognitive area, $43 \%$ of them are in affective area and $47 \%$ of them are in psychomotor area. The attainments which were shown in bold can have more than one area skill. 
Table 7. Distribution of the Attainments from Visual Arts Lesson on 7th Grade According to Cognitive, Affective and Psychomotor Areas

\begin{tabular}{ccc}
\hline Learning Area: Creating Awareness In Visual Arts & \\
Cognitive Area & Affective Area & Psychomotor Area \\
2. attainment & 9. attainment & 1. attainment \\
3. attainment & & 3. attainment \\
4. attainment & & 6. attainment \\
5. attainment & & 8. attainment \\
6. attainment & & 9. attainment \\
7. attainment & & \\
8. attainment & & \\
Cognitive Area & Affective Area & Psychomotor Area \\
1. attainment & 2. attainment & 8. attainment \\
3. attainment & 5. attainment & 10. attainment \\
4. attainment & 6. attainment & \\
5. attainment & 7. attainment & \\
6. attainment & 8. attainment & \\
7. attainment & 9. attainment & \\
Learning Area: Museum Consciousness & & Psychomotor Area \\
Cognitive Area & Affective Area & 9. attainment \\
4. attainment & 1. attainment & 10. attainment \\
5. attainment & 2. attainment & \\
6. attainment & 3. attainment & \\
9. attainment & 8. attainment & \\
& 9. attainment & \\
& 10. attainment & 11. attainment
\end{tabular}

\section{Classification of the Attainments from Visual Arts Lesson on 7th Grade}

There are totally 30 attainments from the visual arts lesson on the 7th grade of primary education. 17 of these attainments are in cognitive area, 14 of them are in affective area and 9 of them are in psychomotor area. When it is counted by percentages, it is seen that $56 \%$ of the attainments are in cognitive area, $46 \%$ of them are in affective area and $30 \%$ of them are in psychomotor area. The attainments which were shown in bold can have more than one area skill.

\section{Classification of the Attainments from Visual Arts Lesson on 8th Grade}

Table 8. Distribution of the Attainments from Visual Arts Lesson on 8th Grade According to Cognitive, Affective and Psychomotor Areas

\begin{tabular}{ccc}
\hline Learning Area: Creating Awareness In Visual Arts & \\
Cognitive Area & Affective Area & Psychomotor Area \\
4. attainment & 1. attainment & 1. attainment \\
5. attainment & 5. attainment & 2. attainment \\
6. attainment & 7. attainment & 3. attainment
\end{tabular}

(C) 2012, European Journal of Educational Research, 1(2), 65-83 


\begin{tabular}{lcc} 
& & 4. attainment \\
& & 5. attainment \\
Learning Area: Visual Arts Culture & & Poinment \\
Cognitive Area & AFFECTIVE AREA & P. attainment \\
1. attainment & 1. attainment & 11. attainment \\
2. attainment & 4. attainment & \\
3. attainment & 5. attainment & \\
6. attainment & 11. attainment & \\
7. attainment & 12. attainment & \\
8. attainment & & \\
9. attainment & & \\
10. attainment & & \\
11. attainment & & \\
12. attainment & & Psychomotor Area \\
Cognitive Area & & 3. attainment \\
1. attainment & & 4. attainment \\
2. attainment & Affective Area & 5. attainment \\
& 5. attainment & 6. attainment \\
& 7. attainment & 7. attainment \\
\hline
\end{tabular}

There are totally 27 attainments from the visual arts lesson on the 8th grade of primary education. 15 of these attainments are in cognitive area, 11 of them are in affective area and 13 of them are in psychomotor area. When it is counted by percentages, it is seen that $55 \%$ of the attainments are in cognitive area, $40 \%$ of them are in affective area and $48 \%$ of them are in psychomotor area. The attainments which were shown in bold can have more than one area skill.

\section{Conclusion and Suggestions}

It gas confirmed that there are attainments for bringing cognitive, affective and psychomotor area skills in every levels from 1st grade to 8th grade in Primary Education (1-8. Grades) Visual Arts Curriculum. It has been seen that attainments include more than one skill in every level. This means that the written attainment can be stimulant to cognitive, psychomotor and affective skills at the same time. This situation is thought as a feature which makes planning the education of the student for a teacher and motivates the student for the lesson. It is seen that the attainments on the 1st grade are focused on teaching the psychomotor skills with a suitable qualification of "learning by living/doing" considering the skills and attention time of the student during the lesson. Besides, it is conspicuous that the number of attainment for affective learning is pretty much. If we consider that affective skills are the skill which is difficult to bring, it is the most important one among the skills and habits which are aimed to be brought beginning from 1st grade.

When the distribution of the attainments on 2nd and 3rd grades are analyzed, it is possible to see that targets for bringing cognitive, affective and psychomotor skills are close to each other and at equal rates. Additionally, it is seen that cognitive skills are also regarded conspicuously and the attainments in this qualification are concentrated on. When gains on 4th grade are examined, it is remarkable that the number of the gains consisting affective skills is decreasing. It can be said that a suitable ad- 
justment for primary school students who are 11-12 years old, has been made. As it is known, children at these ages start to tell their opinions about the world. "They start to prefer political preferences and make positive or negative notices by evaluating the events. Because their mental developments are ready for abstract procedures. Making comments and judgments beyond concrete situations are a kind of trial move in the middle childhood". (Bacanl, 2002, p. 49). It is a necessity for children whose cognitive processes are on, to have these gains which equalize these processes affectively. In this respect, the number of the attainments for improving the affective skills on the 4th grade of Primary Education Visual Arts Lesson Curriculum can be increased. When the 5th, 6th and the 8th grades are considered, it is possible to say that attainments in cognitive, affective and psychomotor areas are more balanced and in equal amounts.

In the gains on the 7th grade, there is a remarkable decrease in the number of psychomotor skills and attainment which will support their learning. It is seen that the significance is distributed equally in cognitive and affective areas. It is known that the most frequent behaviors of this period in which students start to discover their bodies, is uncontrollable situations such as cumbersomeness and clumsiness etc. When the wished result cannot be obtained, psychomotor learning skills which are thought to put pressure on the student are neglected in this stage considering the student's growth duty. Nevertheless, the number of these attainments aiming to teach the psychomotor skills can be increased in a more balanced way with the others. The results of this research show that it is determined that attainments including the targets aiming generally cognitive, affective and psychomotor areas in Primary Education Visual Arts Lesson Schedule are suitable for growth duties in every areas.

\section{References}

Ada, Şükrü; Başar Erdoğan; Dağli Abidin; Ekinci Ergin; Ergün Muammer; Gelbal Selahattin; Hoşgörür Vural; Kiroğlu Kasım; Mahiroğlu Ahmet; Taştan Nuray (2008). Eğitim Bilimine Giriş, PegemA Akademi, Ankara.

Bacanli, Hasan (2002). Gelişim ve Öğrenme, Nobel Yayınevi, Ankara.

Bilen, Mürüvvet (1993). Plandan Uygulamaya Öğretim, Takav Matbaacılık, Ankara.

Çepni, Salih (2007). Araştırma ve Proje Çalışmalarına Giriş, Celepler Matbaacılık, Trabzon.

Demirel, Özcan (2007). Eğitimde Program Geliştirme, PegemA Yayıncılık, Ankara.

Ertürk, Ertürk (1993). Eğitimde Program Geliştirme, Hacettepe Üniversitesi, Ankara.

Güven, Meral (2004). Öğrenme Stilleri ile Öğrenme Stratejileri Arasındaki İlişki, T.C. Anadolu Üniversitesi Yayınları; No.165, Eskişehir.

MEB (2007). Görsel Sanatlar Dersi (1-8. Sınıflar) Öğretim Programı ve Kılavuz Kitabı. Devlet Kitapları Müdürlüğ̈̈, Ankara.

Peşkersoy, Eylem; Yildirim, Osman (2008). Görsel Sanatlar Dersi (1-8. Sınıflar) Öğretmen Kılavuz Kitabı, T.C. Millî Eğitim Bakanlığı, Kelebek Matbaacılık, İstanbul.

Sönmez, Veysel (1994). Eğitim Felsefesi, Pegem Personel Geliştirme Merkezi Yayını Nu.15, Ankara.

Tataroğlu, Eylem (2011). Görsel Sanatlar Dersi Kazanımlarının Bilişsel-Duyuşsal-Psikomotor Alan Becerilerinin Aşamalarına Göre Sınıflandırılması, Milli Eğitim Dergisi, Sayı:190, s. 122-144.

Variş, Fatma (1976). Eğitimde Program Geliştirme “Teori ve Teknikler", Kalite Matbaası, Ankara.

Yildirim, Cemal (1987). Eğitim Bilimleri-Eğitim Felsefesi, Anadolu Üniversitesi Açıköğretim Fakültesi, Ders Kitapları Yayın Nu: 203/EF, Eskişehir.

(C) 2012, European Journal of Educational Research, 1(2), 65-83 


\section{APPENDIX}

\section{APPENDIX-1: Visual Arts (1-8 Grades) Gains from the Lesson}

\section{GAINS FROM VISUAL ARTS ON 1ST GRADE}

\section{Learning Area: Figuration On Visual Arts}

1. The student performs art by using different genres of various art branches such as a song, a poem, a tale, a memoir etc.

2. The student uses the line on his visual works.

3. The student realizes different subjects by exercising textured works.

4. In his visual works, some ingredients such as "tall-short", "big-small", "thick-thin" are used.

5 . The students relate different materials to each other.

6. The student expresses his feelings and ideas via different visual art techniques.

7. The student enjoys performing his works and sharing this feeling.

\section{Learning Area: Culture Of Visual Arts}

1. The student shares the experiences that he gained by nature walks.

2. The student realizes the negative points which make his environment ugly.

3 . The student expresses loving respecting the nature visually.

4. The student designs visual works by using various objects from the nature.

5. The student accepts the necessity of protecting natural habitat while organizing his own living space.

6 . The student accepts the importance of keeping his house, room, classroom and his school clean and tidy.

7. The student says what he sees in the shown art-work.

8. The student expresses his feelings and opinions about the shown art-work.

9. The student memorizes the name of the artist.

10. The student performs his own special art-work considering the colors, figures, objects and the subject of the shown art-work.

\section{Learning Area: Museum Consciousness}

1. The student has an idea about museums, art galleries, ruins, historical artifacts, monuments etc.

2. The student enjoys making a museum panel by using the visual documents such as cards, posters about museums, art galleries, ruins, historical artifacts, monuments etc.

3. The student shares his impressions about museums, art galleries, ruins, historical artifacts, monuments etc.

4. The student designs visual works by the impressions that he gained from museums, art galleries, ruins, historical artifacts, monuments etc.

\section{GAINS FROM VISUAL ARTS ON 2ND GRADE}

\section{Learning Area: Figuration On Visual Arts}

1. The student performs visual works by using different genres of various art branches such as a song, a poem, a tale, a memoir etc. 
2. The student performs textured works with different materials on various surfaces by showing texture examples.

3. The student knows simple geometric figures.

4. The student uses simple geometric figures in his visual works.

5. The student knows primary and secondary colors.

6 . The student takes the action of agglomeration, array and placement.

7. The student expresses his feelings and impressions via different visual art techniques.

8. The student enjoys performing his works and sharing this feeling.

\section{Learning Area: Culture Of Visual Arts}

1. The student gives positive and negative examples about the landscape of his environment.

2. The student prettifies his environments with artworks that he likes and his own works.

3. The student expresses that he does not confirm the pollution and disorder in his environment, via visual arts.

4. The student understands the importance of living in a pretty environment.

5. The student evaluates the factors that he sees in the artwork in visual aspects.

6. The student expresses the factors that he likes or dislikes in the artwork with reasons.

7. The student designs visual works which expresses his feelings, impressions, dreams and ideas considering the shown artwork.

\section{Learning Area: Museum Consciousness}

1. The student obeys the rules of the places such as museums, art galleries, ruins, historical artifacts, monuments etc.

2. The student understands the importance of the ruins, historical artifacts, monuments and the artworks in museums and art galleries etc.

3. The student designs visual works of museums, art galleries, ruins, historical artifacts, monuments etc.

4. The students take the pride in having museums, art galleries, ruins, historical artifacts, monuments etc. in his country.

\section{GAINS FROM VISUAL ARTS ON 3RD GRADE}

\section{Learning Area: Figuration On Visual Arts}

1. The student performs visual works by using different genres of various art branches such as a song, a poem, a tale, a memoir, a saga etc.

2. The student gives examples from line types used in games.

3. The student enjoys performing lineal works.

4. The student knows the line types that he meets in his own works, works of artists and his life.

5 . The student creates stains with games on a surface.

6 . The student designs visual works by geometric figures.

7. The student perceives the views of the objects by stains.

8. The student uses line, color, shape and stain relations in his works.

9. The student uses primary and secondary colors in his visual works.

10. The student discovers color richness by mixing the colors.

11. By determining the creatures such as flowers, houses, flowers, birds etc. the student realizes that these creatures have shapes.

12. The student creates original works considering the shapes around him.

(C) 2012, European Journal of Educational Research, 1(2), 65-83 
13. The student expresses his feelings and ideas via different art techniques.

14. The student enjoys performing his works and sharing this feeling.

\section{Learning Area: Culture Of Visual Arts}

1. The student performs visual artworks about the creatures that he likes.

2. The student respects the differences between tastes.

3. The student collects information about the artist of artworks he uses.

4. The student explains how objects, colors, shapes and figures were used in the visual work.

5. The student expresses his feelings and opinions about the shown art-work.

6 . The student benefits from the shown art-work in his visual art works.

\section{Learning Area: Museum Consciousness}

1. The student understands the importance of protecting the artworks in museums.

2. The student discovers the ways of researching on historical artifacts and museums, art galleries, ruins, historical artifacts, monuments etc.

3. The student expresses his feelings and opinions about the artifacts in the museum.

4. The students take the pride in having museums, art galleries, ruins, historical artifacts, monuments etc. in his country.

\section{GAINS FROM VISUAL ARTS ON 4TH GRADE}

\section{Learning Area: Figuration on Visual Arts}

1. The student performs visual works by using different genres of various art branches such as a song, a poem, a tale, a memoir, a saga etc.

2. The student realizes that colors changes according to light.

3. The student paints by using color values.

4. The student argues on the relation between colors and feelings and opinions.

5. The student distinguishes natural and artificial objects.

6. The student gives example of different shapes around him.

7. The student argues what can be the shape contrasts around him.

8. The student realizes center and symmetric balance by considering the examples around him.

9. The student enjoys using the lines in his two-dimensional and three-dimensional works.

10. The student builds with simple three dimensional geometrical figures.

11. The student realizes that objects can be seen differently with different perspectives.

12. The student realizes that he can benefit from natural and artificial object in his visual works.

13. The student expresses his feelings and ideas via different visual art techniques.

14. The student enjoys performing his works and watching his friends' works.

\section{Learning Area: Culture of Visual Arts}

1. The student distinguishes two-dimensional and three-dimensional artworks from each other.

2. The student realizes that there are different views, when it is looked at three-dimensional object from a different perspective.

3. The student accepts that every creature in life has its unique beauty.

4. The student analyses a handcraft work according to its expression, shape, color, originality.

5. The student determines in which respect the local handicrafts are important.

6 . The student designs a visual work considering a local handicraft work.

7. The student knows the difference between picture and photo. 


\section{Learning Area: Museum Consciousness}

1. The student collects pre-information about the ruins, historical artifacts, monuments and the artworks in museums and art galleries etc. around him.

2. The student realizes that museums are classified according to art-work contents as Art Museum, Archeological Museum, Ethnography Museum and Science Museum.

3. The student designs two or three dimensional visual works considering the ruins, historical artifacts, monuments and museums.

4. The student knows about the difference between the original and reproduction.

5. The students take the pride in having museums, ruins, historical artifacts, monuments etc. in his country.

\section{GAINS FROM VISUAL ARTS ON 5TH GRADE}

\section{Learning Area: Figuration on Visual Arts}

1. The student performs visual works by using different genres of various art branches such as a song, a poem, a tale, a memoir, a saga etc.

2. The student makes original colorful compositions with dots, spots and stains by showing examples of creatures with the point effect around him.

3. The student enjoys making original designs with three dimensional materials which have point and line effect.

4. The student distinguishes warm colors from cool colors.

5. The student designs visual works by using opposite colors.

6 . The student realizes the color mismatches around him.

7. The student uses the center, symmetrical and asymmetrical balance in his works.

8. The student uses spots, lines, colors, shapes and stain repeats which he realizes in the formation of visual texture, in his works.

9. The student expresses his feelings and ideas via different visual art techniques.

10. The student enjoys performing his works and watching his friends' works.

\section{Learning Area: Culture of Visual Arts}

1. The student determines which visual art branch an art-work belongs to.

2. The student knows that the same subject can perform with different materials, techniques and style.

3. The student realizes that tastes can change according to some factors such as time, education, culture etc.

4. The student knows natural and historical beauties around him.

5. The student explains why the features of the natural beauties and historical structures around him should not be destroyed with reasons.

6. The student uses the natural and historical beauties as a resource for his works.

7. The student can distinguish the artist from the craftsman.

\section{Learning Area: Museum Consciousness}

1. The student wants to visit museums, ruins, monuments etc.

2. The student discusses the relation between the works and information he meets in museums, ruins, monuments etc. and the history with his friends. 
3. The student learns the terms, "restoration" and "conservation".

4. The student designs visual works considering the historical artifacts that he sees.

5. The students take the pride in having museums, ruins, historical artifacts, monuments etc. in his country.

\section{GAINS FROM VISUAL ARTS ON 6TH GRADE}

\section{Learning Area: Figuration on Visual Arts}

1. The student uses the point and line effect in his three dimensional works.

2. The student discusses how an artist uses the light and shadow to determine the place.

3. The student uses the light and shadow to have three dimensionality impressions in his compositions.

4. The student discusses the balance factors in art-works.

5. The student realizes that colors are influential for reflecting the feelings and moods.

6. The student uses similarities, contrasts and repeats in his two and three dimensional works.

7. The student creates compositions with light- medium- dark values of colors, regarding that each color has a stain value.

8. The student is inspired from different genres of various art branches such as a song, a poem, a tale, a memoir etc. in his works.

9. The student enjoys performing his works and watching other's works.

\section{Learning Area: Culture of Visual Arts}

1. The student determines the difference between "art-work" and "industrial work".

2. The student gives examples of our national culture inheritances.

3. The student discusses the importance of fine arts in identifying the nations.

4. The student designs visual works which introduces and reflects the national culture.

5. The student guesses the given opinions, and opinions which are possibly given and feelings in the shown visual art work.

6 . The student designs visual works considering the impressions that he gets from the shown visual artworks.

7. The student realizes that the qualifications in arts are determined by human hand and sensibility.

8. The student compares the natural beauty and artistic beauty with each other.

\section{Learning Area: Museum Consciousness}

1. The student relates works in museums to the sense of art in the time that they belong to.

2. The student respects different cultures.

3. The student knows Anatolian civilizations via artifacts.

4. The student uses artifacts from Anatolian civilizations in his visual designs.

5. The student discusses the contributions of designing a visual work considering the artifacts in museums to his cultural savings.

6. The students take the pride in having museums, ruins, historical artifacts, monuments etc. in his country.

GAINS FROM VISUAL ARTS ON 7TH GRADE 


\section{Learning Area: Figuration on Visual Arts}

1. The student performs visual works by using different genres of various art branches such as a song, a poem, a tale, a memoir, a saga etc.

2. The student perceives that objects and figures have geometrical shapes.

3. The student converts the objects and figures into geometrical shapes clearly.

4. The student distinguishes the visual figuration factors in his art-works.

5. The student gives examples from his environment and nature for artistic figuration principles.

6. The student uses color harmonies in his compositions.

7. The student relates positive and negative shapes.

8. The student expresses his feelings and ideas via different visual art techniques.

9. The student enjoys performing his works and sharing with the people around him.

\section{Learning Area: Culture of Visual Arts}

1. The student expresses the role of nature in the creation of an art-work with examples.

2. The student realizes the contribution of feelings to the artistic creativity.

3. The student distinguishes abstract and concrete explicanda in art-works.

4. The student distinguishes the functions of symbols, signals, colors and stains in a graphic design work.

5. The student understands the importance of pictograms as universal visual symbols in daily life.

6. The student discusses how the artist is affected by his environment, considering the subject of the shown art-work.

7. The student realizes that an art-work is a communication tool between artist and the society.

8. The student researches on the art-works and artists that he is interested in.

9. The student learns that the beauty concept standards can differ according to cultures.

10. The student designs visual works by getting inspired by the local features of where he lives.

\section{Learning Area: Museum Consciousness}

1. The student learns that museums are the place where national and universal products are carried from past to the future.

2. The student accepts the importance of protecting our national culture.

3. The student realizes the importance and the requirement of registration of historical artifacts and artworks.

4. The student understands the features of art-works.

5. The student explains the features of historical artifacts.

6. The student determines the differences between the features of historical artifacts and art-work.

7. The student researches on the art-works that he is interested in.

8. The student comprehends that it is a national duty to protect the historical artifacts for everyone.

9. The student discusses the results of historical artifact smuggling.

10. The students take the pride in having museums, ruins, historical artifacts, monuments etc. in his country.

11. The student comprehends that historical artifacts should be delivered to museums.

\section{GAINS FROM VISUAL ARTS ON 8TH GRADE}

\section{Learning Area: Figuration on Visual Arts}

(C) 2012, European Journal of Educational Research, 1(2), 65-83 
1. The student makes visual figurations by relating different genres of various art branches such as a song, a poem, a tale, a memoir etc.

2. The student develops an effect of depth with color tones in his visual works.

3. The student creates original compositions by using artistic organization principles.

4. The student discusses the role of geographical and cultural factors in choosing colors.

5. The student expresses his feelings and ideas via different visual art techniques.

6. The student understands that the lines are personal.

7. The student enjoys performing his works and sharing with the people around him.

\section{Learning Area: Culture of Visual Arts}

1. The student accepts that art has its own universal original language.

2. The student collects information about different art movements.

3. The student realizes that different esplanade create different art branches.

4. The student knows that he can express his feeling and opinions via different visual art branches.

5 . The student wants to learn about life stories of artists whose art-works he meets.

6. The student explains how visual figuration factors are organized in an art-work according to artistic organization principles.

7. The student questions the variety of subjects in art-works.

8. The student discusses the effect of various events, time's thought and belief systems, geographical features on the creation of the visual art-work.

9. The student gives examples of the art's being a way for culture exchange.

10. The student explains the effect of technological developments on visual arts.

11. The student designs visual works which reflects his feelings, opinions and impressions.

12. The student makes an aesthetical judgment about an art-work.

\section{Learning Area: Museum Consciousness}

1. The student collects information about persons who guided the establishment of Turkish museology.

2. The student researches on the process of the art-works' arrival at the museum.

3. The student makes online visits to a museum.

4. The student creates visual works about the museum about which he makes online research.

5. The student uses information technologies to support protecting the cultural inheritance.

6. The student designs visual works considering historical artifacts, constructions and monuments etc.

7. The students take the pride in having museums, ruins, historical artifacts, monuments etc. in his country.

8. The student realizes the relation between history, culture and visual arts. 